\title{
EVALUASI SISTEM PENGELOLAAN DAERAH IRIGASI DI PROVINSI SULAWESI UTARA
}

\author{
Leo Hengky Kalesaran, \\ Jailani Husain, \\ Bobby V. J. Polii
}

\begin{abstract}
The objectives of this research were: (1) to get the new information and knowledge about the irrigation area system management existing in North Sulawesi Province, (2) to study about the complexity aspects of the irrigation area system management, and (3) to know the model of irrigation area management system in North Sulawesi Province, and to propose the alternative one. This research was designed as descriptive one. Data and information were collected through in-depth interviews and by questionnaires. Twenty one representatives of irrigation stakeholders in North Sulawesi were selected as respondents by using purposive sampling method. The result showed that (1) the distribution and management of irrigation area in North Sulawesi Province was determined by the criteria and status authority stated in the Ministry of Public Work and Public Housing of Indonesia Regulation which consisted of: Irrigation area authorized to the central government, provincial government, and regency or municipal government. It was found that $25.162 \mathrm{Ha}$ from $80.792 \mathrm{Ha}$ of potential irrigated land had not been converted as irrigated land. (2) From those two main components of irrigation areas, which are irrigation infrastructure, and irrigation land, it was found that the government more focused their activities and budget in supporting the irrigation infrastructure operation and maintenance, while other factors regarding to the management of irrigation land, such as water catchment area condition, the local commission of irrigation, regulation system, inter-sector coordination system, the direction of sector policies development, and the environment and sustainable development concerns had not got enough attention, and (3) The model of irrigation area management system existing in North Sulawesi Province, was still a "close system". It is recommended to change this to be an "open system" so that other related sectors can get involved. *ghmk*
\end{abstract}

Keywords: evaluation, irrigation area management, North Sulawesi

\begin{abstract}
ABSTRAK
Tujuan penelitian ini adalah: 1) untuk mendapatkan gambaran dan pemahaman terkini tentang kondisi daerah irigasi di Provinsi Sulawesi Utara, 2) mengkaji aspek-aspek atau faktor-faktor yang berhubungan dengan program, atau sistem pengelolaan daerah irigasi, serta 3) memahami model sistem pengelolaan daerah irigasi di Provinsi Sulut, dan mengusulkan alternatif model sistem. Pengambilan data dilakukan melalui survey dan wawancara, menggunakan alat bantu kuesioner dan catatan-catatan penelitian. Sampel responden dipilih secara sengaja (purposive sampling) dari instansi-instansi. Jumlah sampel yang dipilih yaitu sebanyak 21 responden. Daftar pertanyaan sebagai alat bantu, dirancang berbeda-beda sesuai lingkup tugas responden dan keterkaitannya dengan permasalahan daerah irigasi. Kesimpulan temuan dalam penelitian ini adalah (1) penyebaran dan pengelolaan Daerah irigasi di Provinsi Sulawesi Utara ditentukan berdasarkan kriteria penetapan status daerah irigasi sesuai kewenangan yang diatur berdasarkan Peraturan Menteri Pekerjaan Umum dan Perumahan Rakyat, yang terdiri dari: Daerah Irigasi Kewenangan Pemerintah (Pusat), Kewenangan Pemerintah Provinsi, dan Kewenangan Pemerintah Kabupaten/Kota. Dari luas keseluruhan daerah irigasi potensial yang ada sebesar $80.792 \mathrm{Ha}$, masih terdapat 25.162 diantaranya yang tidak atau belum dikelola menjadi daerah irigasi fungsional. (2) Dari dua komponen utama pada daerah irigasi, yaitu jaringan irigasi, dan kesatuan lahan irigasi, ternyata kebijakan-kebijakan yang ada pada umumnya hanya menyangkut pembinaan dan pengelolaan jaringan irigasi, sedangkan menyangkut pembinaan dan pengelolaan kesatuan lahannya yang mencakup antara lain: aspek keterkaitan dengan sektor lain, aspek peraturan perundang-undangan, keterkaitan dengan kebijakan sektoral, kepentingan lingkungan hidup dan pembangunan berkelanjutan, dan lain-lain, hampir tidak mendapat perhatian, dan permasalahan-permasalahan yang ada masih belum mendapat penanganan. (3) Model sistem pengelolaan daerah irigasi di Provinsi Sulawesi Utara saat ini merupakan model sistem yang tertutup dengan komponen (pelaku) utama Sektor Kementerian PUPR yaitu Bidang Sumberdaya Air Dinas Pekerjaan Umum dan UPT Balai Wilayah Sungai. Berdasarkan hasil penelitian ini maka direkomendasikan untuk mengubah ini menjadi "sistem terbuka" sehingga sektor terkait lainnya dapat terlibat.
\end{abstract}

Keywords: evaluasi, pengelolaan daerah irigasi, Sulawesi Utara 


\section{PENDAHULUAN}

Di Provinsi Sulawesi Utara hingga saat ini telah dibangun sebanyak 384 daerah irigasi, yang bervariasi mulai dari tingkatan irigasi teknis, semi teknis, hingga irigasi sederhana (pedesaan), dengan luas daerah irigasi masing-masing yang juga bervariasi. Berdasarkan Peraturan Menteri Pekerjaan Umum dan Perumahan Rakyat (Permen PUPR) Nomor 14/PRT/M/2015 Tanggal 21 April 2015 Tentang Kriteria dan Penetapan Status Daerah irigasi, tanggungjawab pengembangan dan pengelolaan daerah irigasi ditentukan berdasarkan:

a. kedudukannya pada wilayah pemerintahan, yang terdiri dari: daerah irigasi strategis nasional yang luasannya lebih dari $10.000 \mathrm{Ha}$, daerah irigasi lintas negara, daerah irigasi lintas daerah provinsi, daerah irigasi lintas daerah kabupaten/kota, serta daerah irigasi yang terletak utuh pada satu kabupaten/kota;

b. kewenangan dan tanggung jawab sesuai tingkatan pemerintahan, yang meliputi: daerah Irigasi kewenangan pemerintah (pusat) dengan luas yakni lebih besar dari $3000 \mathrm{Ha}$, daerah irigasi kewenangan pemerintah provinsi dengan luas areal $1000 \mathrm{Ha}$ hingga $3000 \mathrm{Ha}$, dan daerah irigasi kewenangan pemerintah kabupaten/kota dengan luas kurang dari $1000 \mathrm{Ha}$.

Di dalam Permen PUPR Nomor 14 Tahun 2015 tersebut telah dinyatakan juga bahwa kewenangan instansi untuk menangani pengelolaan irigasi, yaitu pemerintah, pemerintah provinsi, maupun pemerintah kabupaten/kota, hanya terbatas pada jaringan atau saluran primer dan sekunder, sedangkan kewenangan dan tanggung jawab pengelolaan pada jaringan tersier diberikan kepada petani pemakai air. Pada Tabel 1. Diperlihatkan tentang jumlah daerah irigasi di Provinsi Sulut berdasarkan kewenangan dan tanggungjawab pengelolaannya oleh Pemerintah.

Dari Tabel 1 dapat dilihat bahwa luas potensial keseluruhan daerah irigasi di Provinsi Sulut saat ini, yaitu sebesar $80.792 \mathrm{Ha}$ dan luas fungsionalnya sebesar $55.630 \mathrm{Ha}$ (68,85 persen). Data ini, jika dibandingkan dengan data luas daerah irigasi yang ditetapkan berdasarkan Kepmen PU Nomor 390/KPTS/M/2007, sekitar 8 tahun sebelumnya, luas fungsional dari keseluruhan daerah irigasi ini relatif tidak mengalami peningkatan, masih terdapat sebesar 25.162 Ha potensi daerah irigasi yang tidak dikelola menjadi lahan beririgasi. Dibandingkan dengan luas keseluruhan lahan pertanian di Sulut yaitu sebesar 929.086 Ha (BPS, 2014), luas lahan beririgasi (fungsional) tersebut hanya sebesar 5,99 persen, padahal, dalam rangka mendukung strategi pembangunan daerah menuju swasembada beras dan swasembada pangan sebagaimana diarahkan dalam RPJMD Provinsi Sulut Tahun 2010-2015, peningkatan infrastruktur pertanian termasuk perluasan lahan beririgasi masih sangat diperlukan. Luas daerah irigasi yang tidak dikelola sebesar $25.162 \mathrm{Ha}$ sebagaimana disebut di atas, jika dibandingkan dengan luas daerah irigasi Sangkup yang baru dibangun di kabupaten Bolaang-Mongondow Utara, yaitu sebesar 3.601 Ha, maka luas tersebut setara dengan tujuh proyek irigasi Sangkup. Untuk membangun satu proyek irigasi seperti Irigasi Sangkup memerlukan biaya yang relatif besar, selain itu, di Provinsi Sulut saat ini tidaklah mudah untuk mendapatkan areal yang memenuhi syarat untuk pembangunan jaringan irigasi baru. Pasandaran (2005) mengingatkan, bahwa dengan semakin meningkatnya populasi penduduk dan semakin terbatasnya penyediaan lahan, ketersediaan lahan perkapita untuk produksi pertanian akan semakin berkurang. Oleh sebab itu, selain upaya-upaya yang dilakukan oleh Bidang Sumberdaya Air Dinas Pekerjaan Umum Provinsi Sulut dan UPT Balai Wilayah Sungai Kementerian PUPR Provinsi Sulawesi Utara, Dinas Pertanian dan Peternakan Provinsi Sulutpun telah melakukan upaya-upaya peningkatan luas lahan persawahan dengan membangun/ memperluas infrstruktur pada jaringan irigasi tersier, termasuk mengembangkan lahan-lahan sawah tadah hujan dan perluasan lahan untuk penanaman padi ladang.

Tabel 1. Luas Daerah Irigasi (DI) di Provinsi Sulut Berdasarkan Kewenangan

\begin{tabular}{lccc}
\hline \multicolumn{1}{c}{$\begin{array}{c}\text { Kewe- } \\
\text { nangan }\end{array}$} & $\begin{array}{c}\text { Jumlah } \\
\text { DI }\end{array}$ & \multicolumn{2}{c}{ Luas Daerah (Ha) } \\
& & Potensial & $\begin{array}{c}\text { Fung- } \\
\text { sional }\end{array}$ \\
\hline $\begin{array}{l}\text { Pemerintah } \\
\text { (pusat) }\end{array}$ & 4 & 20.602 & 10.354 \\
Provinsi & 12 & 17.633 & 14.183 \\
Kab./Kota & 288 & 42.557 & 31.093 \\
\hline Jumlah & 304 & 80.792 & 55.630 \\
\hline \multicolumn{2}{l}{ Sumber : Permen PUPR No.14/PRT/M/2015 }
\end{tabular}


Dibalik upaya-upaya yang telah dilaksanakan oleh instansi-instansi sebagaimana disebut di atas untuk memantapkan dan meningkatkan luas fungsional daerah irigasi, terdapat indikasiindikasi ancaman, hambatan dan kendala dalam pengelolaan daerah irigasi, seperti antara lain: rusaknya lahan pada daerah hulu irigasi sebagai area tangkapan dan resapan air (water-catchment area), adanya potensi pencemaran kualitas air akibat kegiatan pertambangan liar yang menggunakan senyawa air raksa $(\mathrm{Hg})$, konversi lahan yang dilakukan pada daerah hulu maupun di dalam daerah irigasi dengan berbagai faktor penyebabnya, anomali iklim yang menyebabkan kekeringan atau banjir, terbatasnya peraturan perundang-undangan dan kebijakan sektor pembangunan, lemahnya koordinasi program dan integrasi secara lintas sektor, serta belum tegasnya kepentingan lingkungan hidup dan pembangunan berkelanjutan, dan lain-lain, yang bila hal-hal ini tidak ditata atau ditangani dengan baik, dapat menghambat pencapaian target-target pembangunan daerah dan nasional di Provinsi Sulawesi Utara. Adanya upaya pemerintah untuk membangun berbagai waduk dan bendungan di seluruh Indonesia untuk menunjang program swasembada pangan dan kedaulatan pangan, yang berimplikasi pada pembiayaan investasi publik yang relatif besar, seyogyanya didukung dengan pengetahuan dan pengalaman yang diperoleh dari program-program pengembangan irigasi yang selama ini telah dilakukan, tetapi kajian-kajian atau evaluasi program tentang daerah irigasipun relatif tidak tersedia. Oleh sebab itu, salah satu tindakan manajemen yang sangat dibutuhkan dan relevan untuk ditempuh pada saat penting bagi keberlangsungan suatu program adalah evaluasi (Savva dan Frenken (2002), sebagaimana yang akan dilakukan dalam penelitian ini.

Tujuan penelitian ini adalah: 1) untuk mendapatkan gambaran dan pemahaman terkini tentang kondisi daerah irigasi di Provinsi Sulawesi Utara, 2) mengkaji aspek-aspek atau faktor-faktor yang berhubungan dengan program, atau sistem pengelolaan daerah irigasi, serta 3) memahami model sistem pengelolaan daerah irigasi di Provinsi Sulut, dan mengusulkan alternatif model sistem.

\section{METODE PENELITIAN}

\section{Tempat dan Waktu Penelitian}

Penelitian ini dilaksanakan di beberapa daerah/lokasi kedudukan dari penjabat pemerintahan yang terkait dengan aspek-aspek pengelolaan daerah irigasi, yaitu: di kota Manado (tempat kedudukan instansi pemerintah Provinsi Sulut), Kabupaten Minahasa, Kabupaten Minahasa Selatan, dan Kabupaten Minahasa Utara. Pelaksanaan penelitian dilakukan sejak bulan Oktober 2015 hingga bulan Desember 2015.

\section{Teknik Pengumpulan Data}

Pengambilan data dilakukan melalui survey dan wawancara, menggunakan alat bantu kuesioner dan catatan-catatan penelitian, terhadap penjabat pemerintahan dan instansi/pihak yang berkaitan/memiliki kewenangan di bidang pengelolaan sumberdaya air, pertanian, lingkungan hidup, pengelolaan DAS, serta perizinan.

Sampel responden dipilih secara sengaja (purposive sampling) dari instansi-instansi, yaitu: UPT Balai Wilayah Sungai Kementerian PUPR Provinsi Sulut (yang dinilai dapat mewakili daerah irigasi "besar" dan "wilayah sentra produksi Bolaang Mongondow"), Bidang SDA Dinas PU Provinsi Sulut, Dinas Pertanian dan Peternakan Provinsi Sulut, UPT Balai Pengelola DAS Tondano (yang wilayah kerjanya menyebar di seluruh Provinsi Sulut); Penjabat Bidang SDA Dinas PU, Bidang Pengelolaan Lahan Air/ Prasarana Dinas Pertanian, Badan Lingkungan Hidup, dan Badan Perizinan pada beberapa kabupaten/kota yaitu: Kabupaten Minahasa, Kabupaten Minahasa Selatan, dan Kabupaten Minahasa Utara (yang dianggap mewakili daerah irigasi "kecil" dan "wilayah sentra produksi Minahasa"), serta mewakili Pengurus Perkumpulan Petani Pemakai Air (P3A). Daftar 
pertanyaan sebagai alat bantu, dirancang berbedabeda sesuai lingkup tugas responden dan keterkaitannya dengan permasalahan daerah irigasi. Jumlah sampel yang dipilih yaitu sebanyak 21 responden.

\section{Indikator Evaluasi/Aspek-aspek Kajian}

Di dalam Permen PUPR Nomor 12 Tahun 2015, terdapat beberapa indikator kinerja suatu sistem irigasi yang meliputi: prasarana fisik, produktivitas tanaman, sarana penunjang, organisasi personalia, dokumentasi, dan kondisi kelembagaan P3A. Jika mencermati berbagai permasalahan yang ada pada suatu daerah irigasi, ternyata permasalahannya relatif lebih kompleks dan terdapat beberapa indikator penting yang tidak tercakup di dalam Permen PUPR Nomor 12 Tahun 2015, sehingga aspek-aspek yang dikaji dalam penelitian ini diformulasi kembali disesuaikan dengan jangkauan pelaksanaannya, yang meliputi: (1) Keadaan Umum dan Penyebaran Daerah Irigasi, (2) Pengelolaan Jaringan Irigasi, (3) Pengelola Air Irigasi, (4) Kondisi Daerah Hulu Irigasi, (5) Komisi Irigasi, (6) Penerapan Peraturan Perundang-undangan, (7) Koordinasi Lintas Sektor, (8) Arah Kebijakan Pemerintah, (9) Kepentingan Lingkungan Hidup dan Pembangunan Berkelanjutan, serta (10) Model Sistem Pengelolaan Daerah irigasi.

\section{Analisis Data}

Data dan informasi hasil penelitian, berupa data kuantitatif maupun kualitatif, dianalisis secara deskriptif. Terhadap indikator atau aspek berupa kebijakan dan peraturan perundang-undangan, teknik pembahasan dan penulisannya tidak sepenuhnya mengikuti metode-metode kajian hukum tetapi disesuaikan dengan pembahasan deskriptif.

\section{HASIL DAN PEMBAHASAN}

\section{Keadaan Umum dan Penyebaran Daerah irigasi}

Penyebaran daerah irigasi di Provinsi Sulawesi Utara, tidak merata pada seluruh kabupaten/kota, tetapi pada umumnya terdapat pada dua daerah lumbung padi, yang pada masa sebelum berlakunya pemekaran-pemekaran wilayah dan pembentukan daerah-daerah otonomi baru, yaitu daerah atau dalam hal ini disebut "wilayah Bolaang-Mongondow" dan "wilayah Minahasa". Selama sekitar tiga dekade terakhir tidak ada pembangunan jaringan irigasi besar berupa waduk atau bendungan. Pembangunan "waduk Sangkup" yang menghasilkan daerah irigasi Sangkup, direncanakan dan direalisasi pada dekade terakhir ini, seluas 3.601 Ha, atau hanya mencakup 4,46 persen dari keseluruhan luas potensi daerah irigasi di Sulut. Dengan relatif kecilnya luas daerah irigasi yang ada dibandingkan dengan luas lahan pertanian di Provinsi Sulut (lihat Tabel 2), maka pemerintah dan pemerintah daerah perlu mengkaji kembali keberadaan daerah irigasi yang belum dijadikan lahan beririgasi seluas $25.162 \mathrm{Ha}$. Jika hal ini dibiarkan, maka masyarakat tidak memperoleh manfaat atasnya, dan investasi pemerintah (publik) yang begitu besar untuk membangun infrastruktur yang ada, serta pengeluaran anggaran-anggaran operasional, pemeliharaan dan rehabilitasi jaringan irigasi selama bertahun-tahun akan menjadi mubazir dan cenderung merugikan negara. Oleh karena itu, pemerintah atau pemerintah daerah, sesuai kewenangannya perlu melakukan peninjauan ulang dan inventarisasi atas lahan-lahan yang belum dijadikan lahan beririgasi (sawah), serta menentukan kebijakan dan skenario-skenario penanganan masalah.

Tabel 2. Luas Daerah Irigasi dan Luas Lahan Pertanian di Sulut

\begin{tabular}{ccc}
\hline $\begin{array}{c}\text { Luas Daerah Irigasi } \\
\text { (fungsional) }\end{array}$ & $\begin{array}{c}\text { Lahan Kering } \\
\text { (bukan sawah) }\end{array}$ & Total Luas Lahan Pertanian \\
\hline $55.630 \mathrm{Ha}$ & $866.241 \mathrm{Ha}$ & $929.086 \mathrm{Ha}$ \\
\hline
\end{tabular}

Sumber : Badan Pusat Statistik (2014) 
Hasil penelitian menunjukkan bahwa konversi lahan pada daerah irigasi yang semakin meluas dan mengakibatkan pengalihan status/peruntukan lahan melalui pembangunan sarana pemukiman/ perumahan, sarana usaha, dan peruntukanperuntukan lainnya, yang berdampak langsung maupun tidak langsung terhadap berkurangnya daerah irigasi, hendaknya dapat dilakukan pencegahan sesuai dengan peraturan perundangundangan yang ada. Sehubungan dengan hal ini, pemerintah yang berkewenangan terutama di kabupaten/kota, perlu melakukan penyuluhanpenyuluhan dan sosialisasi tentang ketentuan atau kebijakan-kebijakan yang berlaku.

\section{Pengelolaan Jaringan irigasi}

Pengelolaan jaringan irigasi yaitu kegiatan berupa operasi dan pemeliharaan jaringan irigasi sesuai kewenangan pemerintah atau pemerintah daerah, dilakukan pada jaringan primer dan sekunder oleh suatu unit "gugus tugas" yang berada di bawah otorisasi dinas pekerjaan umum kabupaten/kota, yang disebut Cabang Dinas atau UPT(D), yang struktur atau susunan pengelolanya sesuai Pedoman Penyelenggaraan Operasi Jaringan Irigasi yang diatur dalam Permen PUPR Nomor 12 Tahun 2015 Tentang Eksploitasi dan Pemeliharaan (EP) Jaringan Irigasi dapat dilihat pada Tabel 3.

Keberadaan gugus tugas pengelola jaringan irigasi ternyata sangat strategis, tidak hanya pada tahap alokasi atau distribusi air pada saluran primer dan sekunder, tetapi pada keseluruhan musim tanam di daerah irigasi, karena peranan gugus tugas ini sebagai sumber dan pengelola data/informasi awal keberadaan (debit) air pada jaringan irigasi sebagai titik awal dalam siklus perencanaan pola tanam dan pembagian air pada petak-petak tersier. Kedudukan dan peranan gugus tugas ini sangat berarti terutama pada saat komisi irigasi ternyata tidak ada atau tidak berfungsi di tingkat kabupaten/kota di seluruh Provinsi Sulawesi Utara. Adanya manual-manual operasi dan pemeliharaan jaringan irigasi berbentuk formulirformulir isian yang telah tersedia pada setiap gugus tugas, telah sangat membantu kelancaran pelaksanaan teknis pengelolaan jaringan irigasi. Melalui gugus tugas dan prosedur operasi yang ada, beberapa indikator usaha tani pada tingkat jaringan tersierpun dapat diketahui/dicatat, antara lain menyangkut luas tanam, perguliran tanaman, musim tanam atau indeks pertanaman, dan produksi padi.

Masalah yang ditemukan dalam pengelolaan jaringan irigasi adalah (1) menyangkut pengangkatan tenaga-tenaga/staf gugus tugas yang ternyata tidak semuanya merupakan pegawai tetap atau pegawai negeri, (2) adanya pengangkatan staf yang ternyata belum memiliki pengalaman atau kompetensi yang sesuai dengan penempatannya, (3) domisili dari petugas/staf yang bukan pada lokasi jaringan irigasi. Untuk menanggulangi permasalahan kompetensi staf atau petugas, disarankan kepada pemerintah atau pemerintah daerah yang berkewenangan pada daerah irigasi untuk membangun pusat-pusat bimbingan dan pelatihan petugas jaringan irigasi, serta mengupayakan penempatan petugas/staf, walaupun bukan dalam jabatan negeri, tetapi penangkatannya sesuai dengan prinsipprinsip hubungan ketenagakerjaan berdasarkan peraturan perundang-undangan yang berlaku, demi penghargaan terhadap hak-hak konstitusi atau hakhak azasi manusia. Selain itu, pemerintah/pemerintah daerah sepantasnya melakukan peninjauan atau penelitian kembali, untuk melihat sejauh mana sarana-prasarana penunjang yang ada, termasuk bangunan-bangunan pelengkap dan fasilitas petugas pada tiap daerah irigasi telah tersedia atau dapat disediakan.

Tabel 3. Struktur Pengelola/Petugas Operasi Jaringan Irigasi

\begin{tabular}{llc}
\hline \multicolumn{1}{c}{ Jabatan } & \multicolumn{1}{c}{ Kompensasi } & Minimal Pendidikan \\
Kepala Ranting & Mampu melaksanakan tupoksi & Sarjana Muda/D-III \\
\hline Pengamat/ Cabang Dinas/ Konwil/ & di areal irigasi 5.000-7500 Ha & Teknik Sipil \\
Pengamat Juru/Mantri Pengairan & Mampu melaksanakan tupoksi di areal & STM Bangunan \\
& irigasi 750-1.500 Ha & ST/SMP \\
Petugas Operasi Bandung & Mampu melaksanakan tupoksi & ST/SMP \\
Petugas Pintu Air & Mampu melaksanakan tupoksi & \\
Sumber : Permen PUPR No. 12/PRT/M/2015 & \\
\hline
\end{tabular}




\section{Pengelola Air Irigasi}

Pengelolaan air irigasi dilakukan pada dua tingkatan, yaitu (1) pengelolaan air pada jaringan utama (pada saluran primer dan saluran sekunder) yang biasa disebut tata air makro, dan (2) pengelolaan air pada jaringan/saluran tersier atau disebut tata air mikro. Pengelolaan air makro dilakukan oleh unit gugus tugas di bawah kewenangan Dinas Pekerjaan Umum, sedangkan pengelolaan air mikro dilakukan oleh pengurus perkumpulan petani pemakai air (P3A).

Hasil penelitian menunjukkan bahwa selama beberapa tahun terakhir ini ternyata sebahagian pengurus/organisasi P3A berada dalam keadaan kurang aktif atau tidak aktif. Hasil wawancara dengan para responden (pengurus P3A) menggambarkan terjadinya kondisi "transisi" dari pembinaan oleh Dinas pekerjaan Umum Kabupaten/Kota yang beralih ke Dinas Pertanian. Berdasarkan dokumen-dokumen pembinaan P3A yang diterbitkan dalam bentuk peraturan pemerintah dan peraturan menteri, dapat ditarik suatu pemahaman bahwa arah pembinaan P3A melalui Dinas Pekerjaan Umum didasarkan pada kepentingan pengelolaan sumberdaya air berdasarkan Peraturan Pemerintah Nomor 22 Tahun 1982 Tentang Tata Pengaturan Air, yang hakekatnya mencakup banyak keperluan seperti: air minum yang dianggap paling utama, kemudian pertanian, usaha-usaha perkotaan, ketenagaan, industri, pertambangan, lalu lintas air, pengapungan, rekreasi, kesehatan, dan lain-lain. Oleh karena itu, dalam pedoman-pedoman pelaksanaan pengelolaan jaringan irigasi yang diterbitkan oleh Kementerian PUPR hingga saat ini masih tetap memberi peran kepada P3A sebagai pengelola air irigasi. Sementara itu, pembinaan P3A melalui Dinas Pertanian, didasarkan pada kepentingan sesuai PP No. 23 Tahun 1982 Tentang Irigasi, yang menekankan pada penggunaan irigasi pertanian sebagai kegiatan utama. Perubahanperubahan payung hukum peraturan perundangundangan yang terjadi di bidang sumberdaya air dan irigasi memang telah memberi dampak negatif dan mengganggu pengaturan di tingkat pelaksana. Beberapa peraturan yang dijadikan dasar hukum untuk pembinaan petani pemakai air (P3A) pada Kementerian Pertanian adalah; (1) PP No.38 Tahun
2007 Tentang Pembagian Urusan Pemerintahan antara Pemerintah, Pemerintah Daerah Provinsi dan Pemerintah Kabupaten/Kota, (2) Perpres No. 24 Tahun 2010 Tentang Kedudukan Tugas dan Fungsi Kementerian negara serta susunan organisasi dan fungsi Eselon-I kepada Kementan untuk menetapkan Pedoman Pembinaan dan Pemberdayaan P3A yang ditindaklanjuti dengan Permentan Nomor 79 Tahun 2012 Tentang Pedoman Pembinaan dan Pemberdayaan P3A. Pada masa yang disebut "transisi" ini, memang terlihat bahwa, untuk kondisi di provinsi Sulawesi Utara yang penggunaan utama air irigasi adalah untuk keperluan irigasi pertanian, tetapi pihak pengelolanya adalah pengurus $\mathrm{P} 3 \mathrm{~A}$ yang tidak semuanya dan tidak harus merupakan anggota masyarakat yang profesinya pertanian khususnya padi sawah, telah menciptakan suatu suasana semacam "kesenjangan" antara pengurus P3A dengan Kelompok Tani. Untuk memperbaiki keadaan ini, maka di waktu-waktu mendatang, selayaknyalah jika pelayanan air irigasi pada suatu daerah irigasi yang hanya melayani irigasi untuk pertanian, maka pengurus P3Anya dipilih dari antara anggota kelompok tani itu sendiri. Pada saat yang sama, dengan diterbitkannya Permen PUPR Nomor 30 Tahun 2015 Tentang Pengembangan dan Pengelolaan Sistem Irigasi, yang ternyata isi dari permen tersebut lebih banyak menyangkut pembinaan pengelolaan irigasi kepada P3A/GP3A/IP3A, maka agar tidak terjadi tumpangtindih pembinaannya, sebaiknya Pengurus P3A yang dibina oleh Kementerian PUPR atau dinas/instansi pelaksana di bawahnya, hanya dibentuk pada daerah irigasi yang memiliki jenisjenis usaha atau penggunaan lain termasuk irigasi untuk pertanian, sehingga keberadaan anggota pengurus yang bukan anggota kelompok tani tersebut dalam kepengurusan P3A mendapat landasannya.

\section{Kondisi Daerah Hulu Irigasi}

Masalah utama pada daerah hulu irigasi yaitu masih adanya kegiatan perusakan-perusakan hutan, pembangunan pemukiman/perumahan, dan aktivitas pertambangan, yang mengakibatkan terjadinya perubahan kondisi daerah hulu irigasi atau daerah aliran sungai (DAS), yang pada gilirannya 
mengurangi kapasitas penyimpanan dan pengaliran air di daerah tangkapan dan resapan air, serta mengurangi stabilitas dan kemampuan lahan pada daerah hulu irigasi dalam pengendalian limpasan permukaan pada saat terjadinya hujan. Terjadinya gangguan-gangguan atau perubahan siklus hidrologi pada daerah hulu irigasi yang sangat nyata dengan adanya anomali iklim pada beberapa tahun terakhir ini yang menciptakan keadaan kemarau yang menyimpang (tidak sama) dari kebiasaan dan mengakibatkan kekeringan, atau kebanjiran, menyebabkan kondisi debit air yang sangat fluktuatif pada jaringan irigasi dan menjurus pada penurunan debit andalan sehingga mengurangi tingkat layanan air untuk kebutuhan irigasi pertanian. Laporan para responden mengungkapkan bahwa selang tahun 2015, kondisi ketersediaan air irigasi pada daerah irigasi kewenangan kabupaten/kota relatif bervariasi tapi pada umumnya mengalami penurunan debit air, sedangkan pada daerah-daerah irigasi kewenangan provinsi secara umum dinilai dalam keadaan cukup disesuaikan dengan pola tanam dan perguliran tanaman yang selama ini dilakukan. Pada daerah irigasi kewenangan pemerintah, kecuali pada daerah irigasi Sangkup yang kondisi debir airnya dinilai cukup karena ditunjang dengan keadaan curah hujan yang mendukung yaitu sebesar $2257 \mathrm{~mm}$ yang diukur pada stasiun pengamat cuaca selama 11 bulan, sejak bulan Januari hingga November 2015 (BMKG Kayuwatu, 2015), selain itu, pada ketiga daerah irigasi lainnya, semuanya mengalami penurunan debit. Pada Tabel 4. ditunjukan tentang gambaran ketersediaan air pada 4 daerah irigasi kewenangan pemerintah dan pada 12 daerah irigasi kewenangan Pemerintah Provinsi Sulut.

\section{Komisi Irigasi}

Komisi irigasi merupakan institusi independen yang dibentuk dan berfungsi antara lain, untuk memberi pertimbangan-pertimbangan dan usulan kebijakan kepada pemerintah/kepala daerah dalam pengelolaan jaringan irigasi, pengelolaan air irigasi, dan kebijakan konversi daerah irigasi. Komisi ini seharusnya ada atau dibentuk di tingkat provinsi dan kabupaten/kota yang memiliki daerah irigasi, tapi ternyata hingga tahun 2015, komisi ini belum dibentuk pada seluruh kabupaten/kota di Provinsi Sulawesi Utara. Dengan dibatalkannya UU No.7 Tahun 2004 Tentang Sumberdaya Air yang secara otomatis menggugurkan keabsahan PP No 20 Tahun 2006 Tentang Irigasi yang menjadi payung hukum pembentukan komisi irigasi pada waktu itu, mengakibatkan peran dan fungsi komisi ini tidak berjalan. Di tingkat Pemerintah Provinsi Sulut, komisi ini telah dibentuk dengan Keputusan Gubernur Sulut Tahun 2014, tapi dengan payung hukum yang sudah tidak berlaku, komisi ini tidak berperan secara optimal. Peraturan Menteri PUPR Nomor 17 Tahun 2015 Tentang Komisi Irigasi yang ditetapkan pada tanggal 21 April 2015 yang mengisyaratkan bahwa semua pemerintah daerah yang memiliki daerah irigasi untuk membentuk komisi irigasi, ternyata juga belum dapat direalisasi. Tidak adanya komisi irigasi yang dalam fungsinya sebagai institusi yang diserahkan kewenangan berdasarkan peraturan yang ada untuk memberi pertimbangan/rekomendasi kepada pemerintah daerah dalam penanganan lahan-lahan beririgasi yang akan dikonversi, mengakibatkan ketentuan ini diabaikan, dan karena ketentuan ini tidak dikoordinasikan atau disinergiskan dengan instansi lain yang berwewenang dalam pengurusan izin-izin, maka ketentuan-ketentuan atau persyaratan yang seharusnya menjadi bagian dari prosedur pemberian izin, akhirnya tidak dapat dilaksanakan. Terjadinya konversi-konversi lahan berupa pembangunan pemukiman, dan usaha-usaha pada daerah irigasi bahkan pada lahan-lahan beririgasi, ternyata masih berlangsung terus dan berpotensi memperkecil daerah irigasi. Untuk mencegah semakin meluasnya kegiatan konversi lahan pada daerah irigasi, komisi irigasi pada kabupaten/kota harus segera dibentuk dan agenda-agenda yang menjadi prioritas antara lain, adalah mempersiapkan kebijakan dan peraturan-peraturan daerah tentang penanganan konversi lahan pada daerah irigasi, dan hal ini sejalan dengan kebijakan di bidang pertanian sebagaimana diatur di dalam PP Nomor 1 Tahun 2011 Tentang Penetapan dan Alih Fungsi Lahan Pertanian Pangan Berkelanjutan.

\section{Penerapan Peraturan Perundang-undangan}

Sejarah panjang tentang pengaturan hak-hak atas air di Indonesia telah berlangsung sejak peraturanperaturan tentang sumberdaya air dan irigasi ditetapkan pada jaman kolonial Belanda. Kepentingan atas air sebagai kebutuhan pokok 
manusia yang strategis menuntut negara untuk mengelola secara adil demi kesejahteraan seluruh bangsa. Diterbitkannya UU No 7 Tahun 2004 Tentang Sumberdaya Air sebagai pengganti Undangundang No 11 Tahun 1974 Tentang Pengairan, pada akhirnya terbukti mengandung kepentingan yang bertentangan dengan konstitusi. Undang-undang Nomor 7 Tahun 2004 ini, yang di dalam konsiderans dan pertimbangan hukum di dalamnya menyatakan bahwa peraturan-peraturan yang ada sebelumnya (yaitu UU No 11 Tahun 1974) telah tidak sesuai dengan tuntutan kebutuhan dan perkembangan zaman dan karena itu juga telah dinyatakan tidak berlaku setelah berlakunya undang-undang yang baru, tetapi dengan dibatalkannya keseluruhan Undang-undang Nomor 7 Tahun 2004 pada tahun 2014 oleh Mahkamah Konstitusi, otomatis menyangkut pengelolaan sumberdaya air atau pengairan, kembali ke Undang-undang lama agar tidak terjadi kekosongan hukum. Pembatalan Undang-Undang ini, setidak-tidaknya telah memperlihatkan adanya perbedaan-perbedaan kepentingan dan upaya perebutan hak penguasaan atas air oleh kalangan tertentu. Implikasi atas dibatalkannya UU Nomor 7 Tahun 2004, adalah goyahnya kekuatan hukum dari berbagai peraturan-peraturan perundang-undangan yang telah ada selama sekitar delapan tahun yang dipayungi oleh undang-undang ini. PP No 20 Tahun 2006 Tentang Irigasi, yang merupakan implementasi UU No 7 Tahun 2004, yang juga dipakai sebagai acuan dalam perundang-undangan lain (misalnya Peraturan Menteri Lingkungan Hidup tentang kegiatan wajib AMDAL, dengan demikian menimbulkan kerapuhan hukum, bila terjadi perdebatan atau konflik perundangundangan atas pasal-pasal terkait yang digunakan dalam peraturan perundang-undangan itu. Mencermati perkembangan produk hukum tentang pembinaan P3A, ada indikasi terjadinya tumpang tindih atau bahkan potensi konflik perundangundangan jika pengaturannya di tingkat pelaksanaan pada level operasional tidak diatur dengan baik. Kewenangan-kewenangan instansi teknis Bidang pengelolaan sumberdaya air dalam pembinaan P3A sebagaimana diatur dalam Permen PUPR Nomor 30/PRT/M/2015 Tentang Pengembangan dan Pengelolaan Sistem Irigasi, yang di dalamnya berisi tertang tentang pembinaan
P3A, seyogyanya dapat dipisahkan secara tegas dengan kewenangan-kewenangan instansi teknis pertanian yang juga membina kelompok P3A, mengingat pasal 3 ayat (1) Permen PUPR Nomor 30/PRT/M/2015 itu sendiri juncto pasal 4 ayat (1) Permen PUPR Nomor 14/PRT/M/2015 Tentang Kriteria dan Penetapan Status Daerah Irigasi yang justru menyatakan bahwa "pengembangan dan pengelolaan sistem irigasi bertujuan mewujudkan kemanfaatan air dalam bidang pertanian". Jadi, pengorganisasian P3A untuk mewujudkan pelaksanaan PP No 22 Tahun 1982 Tentang Tata Pengaturan Air yang mencakup pelayanan air dalam arti bidang-bidang yang luas, dapat menimbulkan kerancuan.

\section{Koordinasi Lintas Sektor}

Satu masalah yang diangkat sebagai topik studi kasus dalam penelitian ini, yakni masalah izin mendirikan bangunan (IMB) pada daerah irigasi. Sebagaimana disinggung pada bagian terdahulu, bahwa ketentuan izin tentang konversi lahan pada daerah irigasi, dikeluarkan pemerintah setelah mendapat pertimbangan atau rekomendasi dari komisi irigasi (lihat PP No 20 Tahun 2006 Tentang Irigasi dan Permen PUPR No 17 Tahun 2015 Tentang Komisi Irigasi). Ketentuan ini ternyata tidak diketahui oleh instansi pengelola perizinan terpadu, dan selama ini, tidak ada sosialisasi atau koordinasi dengan pihak-pihak instansi terkait, sehingga ketentuan yang seharusnya menjadi bagian dari prosedur pemberian IMB, ternyata tidak berlaku. Akibatnya, prosedur pemberian IMB di daerah irigasi tidak dibedakan dengan permohonan izin pada lokasi pemukiman biasa. Demikian juga menyangkut "peta daerah irigasi" yang semestinya menjadi dokumen daerah dan disosialisasi ke berbagai instansi terkait, ternyata tidak dilakukan, sehingga Badan Lingkungan Hidup, misalnya, sebagai instansi koordinasi pengawasan lingkungan hidup, ternyata tidak memiliki agenda atau program pada daerah irigasi, atau program untuk kepentingan daerah irigasi, bahkan Badan Pengelola Daerah Aliran Sungai, BPDAS Tondano, ternyata juga tidak memiliki (tidak mengetahui) tentang "peta daerah irigasi" di Provinsi Sulawesi Utara. Penelusuran lebih lanjut juga membuktikan bahwa pada kantor BPDAS Tondano, tidak ada 
program-program konservasi dan rehabilitasi lahan yang bertema: "penyelamatan daerah irigasi", padahal, secara teoritis, semua daerah irigasi terletak di dalam DAS, dan gangguan atau kerusakan pada daerah DAS, terutama pada daerah hulu DAS, atau daerah hulu irigasi, akan berdampak pada daerah irigasi, karena antara DAS dan daerah irigasi merupakan komponen atau bagian dari suatu daur hidrologi.

Salah satu "produk" manajemen yang berkaitan dengan kepentingan koordinasi secara lintas sektor, adalah terbentuknya forum-forum koordinasi lintas sektor, misalnya Forum Koordinasi Pengelolaan DAS yang dikemas oleh Kantor BPDAS Tondano, dan Dewan Sumberdaya Air atau Dewan Air yang dikemas oleh Bidang Sumberdaya Air Dinas PU Provinsi Sulut (yang saat ini tidak aktif karena belum mendapatkan landasan hukum yang kuat sehubungan dengan pembatalan UU No 7 Tahun 2004). Selain wadah seperti itu, sudah menjadi kelaziman bahwa instansi pemerintah seringkali melakukan rapat-rapat koordinasi, rapat evaluasi, dan sebagainya, mengundang instansi atau pihak lain untuk hadir. Hasil wawancara dengan para responden memperlihatkan bahwa keberadaan dan mekanisme forum atau rapat-rapat yang ada, ternyata tidak efektif, karena selain unsur pihak utama, yang biasanya telah melakukan persiapan-persiapan dengan baik, pihak-pihak "instansi luar" yang diundang biasanya hanya mengirimkan perwakilannya dan tidak memiliki kapasitas pengambilan keputusan atau kebijakan, sehingga forum-forum dan rapat-rapat yang dilakukan terkesan hanya menjadi langkah formalitas, dan akhirnya keputusan-keputusan yang diambil juga menjadi "keputusan sepihak" yang pada gilirannya tidak dapat ditindaklanjuti oleh pihak-pihak lain yang terkait. Pertanyaannya di sini adalah, apakah program atau keputusan yang ditetapkan oleh Forum Koordinasi Pengelolaan DAS, misalnya, dapat ditindaklanjuti oleh instansi/dinas di luar BPDAS?, atau keputusan yang ditetapkan pada suatu rapat koordinasi di satu Dinas PU misalnya, akan ditindaklanjuti oleh Dinas Kehutanan?, dan sebagainya. Kelemahan dari proses atau sistem koordinasi yang ada yaitu karena koordinasi yang dibangun bertumpu pada sektor pelaksana (utama), dan keberadaan sektor lain terkait (sektor penunjang) seakan-akan hanya sebagai pelengkap. Proses atau sistem koordinasi seperti ini harus diubah, dengan menjadikan program sebagai inti dan penggerak utama keterlibatan sektor-sektor dan bukan sebaliknya.

\section{Arah Kebijakan Pemerintah}

Setelah mencermati berbagai ketentuan atau pengaturan tentang daerah irigasi, ternyata hingga saat ini belum ditemukan bentuk kebijakan pemerintah yang secara tegas memberi perhatian atau perlindungan terhadap daerah irigasi, dalam pengertian seluruh aspek yang melekat di dalamnya, selain yang menyangkut jaringan atau infrastruktur irigasi. Dokumen-dokumen pengelolaan DAS di Provinsi Sulut berupa programprogram dan skenario pengelolaan DAS, ternyata dapat dikatakan tidak, atau belum berkesesuaian dengan kepentingan daerah irigasi karena belum memperlihatkan terciptanya area-area program yang terkoneksi antara instansi pengelola DAS dan pengelola sumberdaya air, padahal, dengan diterbitkannya PP Nomor 37 Tahun 2012 Tentang Pengelolaan Daerah Aliran Sungai (DAS) yang diarahkan pada (1) pengelolaan DAS yang dipertahankan dan (2) DAS yang dipulihkan, merupakan peluang yang baik, untuk mengsinergiskannya dan mengintergasikan program perlindungan dan pemeliharaan daerah irigasi ke dalam sistem pengelolaan DAS. dengan upayaupaya perlindungan dan pemeliharaan daerah irigasi. Pada saat yang sama, kebijakan-kebijakan pengelolaan sumberdaya air yang berjalan saat ini yang ditetapkan dengan berbagai peraturan menteri memiliki keterbatasan dan kelemahan serta potensi konflik hukum, terutama ketika muncul peraturanperaturan menteri lain yang juga mengatur tentang suatu hal yang sama. Pembinaan terhadap P3A yang ditetapkan dengan 2 permen, yaitu oleh Kementerian PUPR dan oleh Kementerian Pertanian, seharusnya dapat dikoordinasikan lagi dan diperbaiki untuk menghindari dampak negatif yang dapat terjadi di kemudian hari. 
Tabel 4. Kondisi Ketersediaan Air pada Daerah Irigasi (Permukaan) Kewenangan Pemerintah dan Pemerintah Provinsi Sulut pada Tahun 2015

\begin{tabular}{|c|c|c|c|c|c|}
\hline \multirow[t]{2}{*}{ No. } & \multirow[t]{2}{*}{ Nama Daerah Irigasi } & Kewenangan & \multicolumn{3}{|c|}{ Ketersediaan Air } \\
\hline & & & Tersedia & Cukup & Kurang \\
\hline 1. & DI. Sangkup & Pemerintah & $\sqrt{ }$ & & \\
\hline 2. & DI. Torout & Pemerintah & & $\sqrt{ }$ & \\
\hline 3. & Kosinggolan & Pemerintah & & & $\sqrt{ }$ \\
\hline 4. & Dataran Tinggi Kotamobagu & Pemerintah & & & $\sqrt{ }$ \\
\hline 5. & Ayong Bolangat Baelang & Pemda Sulut & & $\sqrt{ }$ & \\
\hline 6. & Lolak Pinogoluman Monanow & Pemda Sulut & & $\sqrt{ }$ & \\
\hline 7. & Pusian Molong & Pemda Sulut & $\sqrt{ }$ & $\sqrt{ }$ & \\
\hline 8. & Tombolikat Sita & Pemda Sulut & & $\sqrt{ }$ & \\
\hline 9. & Buko Tuntung & Pemda Sulut & & $\sqrt{ }$ & \\
\hline 10. & Noongan & Pemda Sulut & & $\sqrt{ }$ & \\
\hline 11. & Ranoyapo & Pemda Sulut & & $\sqrt{ }$ & \\
\hline 12. & Lahendong & Pemda Sulut & & $\sqrt{ }$ & \\
\hline 13. & Ranombolay & Pemda Sulut & & $\sqrt{ }$ & \\
\hline 14. & Talawaan Meras & Pemda Sulut & & $\sqrt{ }$ & \\
\hline 15. & Moayat-Pawak & Pemda Sulut & $\sqrt{ }$ & & \\
\hline 16. & Buyat & Pemda Sulut & & $\sqrt{ }$ & \\
\hline
\end{tabular}

- Salah satu kebijakan penting di sektor pertanian yang dapat disinergiskan dengan pengelolaan daerah irigasi adalah, dengan diterbitkannya Undang-Undang Nomor 41 Tahun 2009 Tentang Perlindungan Lahan Pertanian Pangan Berkelanjutan. Di dalam undangundang ini beserta peraturan-peraturan pelaksanaannya, mengatur bahwa lahan-lahan pertanian terutama lahan beririgasi dapat diberikan perlindungannya termasuk terhadap upaya-upaya untuk membatasi terjadinya konversi lahan beririgasi. Berkaitan dengan upaya-upaya perlindungan lahan pertanian pangan berkelanjutan ini yang juga harus disinkronisasi dengan kegiatan/program penataan ruang daerah, maka kegiatan-kegiatan yang dibutuhkan atau harus dipersiapkan terutama dalam rangka penyusunan peraturan daerah, harus segera dilakukan.

\section{Kepentingan Lingkungan Hidup dan Pembangunan Berkelanjutan}

Sebagaimana telah dinyatakan oleh Pasandaran (2005) pada bagian awal, bahwa dengan semakin meningkatnya populasi penduduk dan semakin terbatasnya penyediaan lahan, ketersediaan lahan perkapita untuk produksi pertanian semakin berkurang, Amang dan Sawit (1999) juga mengemukakan pendapatnya bahwa, berbicara tentang pangan berarti menyangkut beras, karena sumber pangan utama di Indonesia adalah beras. Dari kedua pendapat tersebut, sangat jelas menunjukkan bahwa fungsi dan peranan daerah irigasi sangat strategis dalam pembangunan bangsa Indonesia. kepentingan lingkungan hidup dan pembanguan berkelanjutan pada daerah irigasi adalah pembangunan yang diharapkan dapat memenuhi kebutuhan generasi saat ini tanpa mengurangi kemampuan generasi mendatang untuk memenuhi kebutuhan mereka (Fauzi, 2004).

Ditinjau dari segi geografis, daerah irigasi di Provinsi Sulut, terutama daerah irigasi kewenangan pemerintah (pusat) yang luasannya lebih dari 3.000 Ha serta daerah irigasi kewenangan pemerintah Provinsi Sulut yang luasnya antara $1.000 \mathrm{Ha}$ hingga $3.000 \mathrm{Ha}$, merupakan hamparan lahan, dan bentang alam yang layak dipandang sebagai kawasan atau bagian dari kawasan lingkungan hidup. Di Provinsi Sulawesi Utara terdapat kawasan-kawasan hutan yang luasnya lebih kecil dari daerah irigasi. Dengan memandang daerah irigasi ini sebagai kawasan atau 
bagian dari kawasan lingkungan hidup, maka perhatian pemerintah dan pemerintah daerah untuk mengelola daerah irigasi seharusnya menggunakan pendekatan lingkungan hidup dan dikelola secara lintas sektor, serta menjamin bahwa semua aktivitas di dalam daerah irigasi termasuk di dalamnya kegiatankegiatan operasi dan pemeliharaan jaringan dapat dilaksanakan secara konsisten dan berkesinambungan. Selama ini terkesan bahwa yang menjadi fokus perhatian pemerintah/pemerintah daerah adalah pembangun-an dan pemeliharaan jaringan (infrastruktur fisik) irigasi, sedangkan aspek-aspek yang berkaitan dengan lahan (merupakan kewenangan instansi lain) relatif terabaikan. Dari fakta-fakta dan informasi yang ditemukan, pada akhirnya menunjukan bahwa daerah irigasi merupakan daerah pertanian yang eksklusif tetapi terabaikan

\section{Model Sistem Pengelolaan Daerah Irigasi}

Sistem pengelolaan daerah irigasi yang ada saat ini merupakan sistem "tertutup" dalam pengertian bahwa semua aktivitas dan proses yang ada, hanya terbatas pada ruang "tupoksi" dari instansi sektor pelaksana utama, yakni sektor PU, padahal masih terdapat banyak hal lain yang berhubungan dengan pengelolaan daerah irigasi tetapi merupakan kewenangan atau tupoksi instansi lain. Sebagai akibat dari masih adanya berbagai hal atau permasalahan di dalam daerah irigasi yang tidak dapat ditangani atau bukan merupakan kewenangan instansi sektor utama, pengawasan terhadap daerah irigasi menjadi lemah, kegiatan konversi lahan beririgasi menjadi peruntukan lain relatif tidak dapat dikendalikan, dan secara umum terkesan bahwa selama ini, daerah irigasi tidak menjadi perhatian dalam perencanaan pembangunan di daerah. Oleh karena itu, pengelolaan daerah irigasi harus dipandang sebagai program lintas sektor yang karenanya harus membuka peluang bagi sektor lain untuk bekerjasama tanpa melanggar batas-batas tupoksi masing-masing sektor. Paradigma pembangunan yang ada saat ini harus diubah dari pembangunan berbasis sektor menjadi pembangunan berbasis program. Masalah pembangunan (lahan) pada daerah irigasi yang terjadi saat ini, antara lain merupakan sumbangan dari penerapan paradigma yang ada. Dengan paradigma program berbasis sektor, sektor-sektor secara otomatis mendapat alokasi dana pembangunan, sehingga program-program yang disusun terkesan "mencari kegiatan untuk memenuhi kuota anggaran yang akan didapat atau menjadi target", dan aspek sinkronisasi serta integrasi program dengan sektor lain menjadi terabaikan.

Dengan menerapkan paradigma pembangun-an berbasis program, model sistem pengelolaan daerah irigasi menjadi sistem yang dinamis, terbuka, dan mampu berkembang secara terkait dengan sistemsistem yang lain yang selama ini ditempatkan di luar sistem. Terdapat dua skenario pengelolaan daerah irigasi yang dapat diusulkan, yaitu, pertama, mengembangkan daerah irigasi sebagai bagian tidak terpisahkan dari (sistem) pengelolaan DAS, dan kedua, menata daerah irigasi sebagai prioritas dalam upaya perlindungan lahan pertanian pangan berkelanjutan.

\section{KESIMPULAN DAN SARAN}

\section{Kesimpulan}

1. Penyebaran dan pengelolaan Daerah irigasi di Provinsi Sulawesi Utara ditentukan berdasarkan kriteria penetapan status daerah irigasi sesuai kewenangan yang diatur berdasarkan Peraturan Menteri Pekerjaan Umum dan Perumahan Rakyat, yang terdiri dari: Daerah Irigasi Kewenangan Pemerintah (Pusat), Kewenangan Pemerintah Provinsi, dan Kewenangan Pemerintah Kabupaten/Kota. Dari luas keseluruhan daerah irigasi potensial yang ada sebesar $80.792 \mathrm{Ha}$, masih terdapat 25.162 diantaranya yang tidak atau belum dikelola menjadi daerah irigasi fungsional.

2. Dari dua komponen utama pada daerah irigasi, yaitu jaringan irigasi, dan kesatuan lahan irigasi, ternyata kebijakan-kebijakan yang ada pada umumnya hanya menyangkut pembinaan dan pengelolaan jaringan irigasi, sedangkan menyangkut pembinaan dan pengelolaan kesatuan lahannya yang mencakup antara lain: aspek keterkaitan dengan sektor lain, aspek peraturan perundang-undangan, keterkaitan dengan kebijakan sektoral, kepentingan lingkungan hidup dan pembangunan berkelanjutan, dan lain-lain, hampir tidak 
mendapat perhatian, dan permasalahanpermasalahan yang ada masih belum mendapat penanganan.

3. Model sistem pengelolaan daerah irigasi di Provinsi Sulawesi Utara saat ini merupakan model sistem yang tertutup dengan komponen (pelaku) utama Sektor Kementerian PUPR yaitu Bidang Sumberdaya Air Dinas Pekerjaan Umum dan UPT Balai Wilayah Sungai.

\section{Saran}

1. Pembinaan/penataan kembali lahan di dalam daerah irigasi terutama pemberdayaan potensi daerah irigasi yang belum dikonversi menjadi daerah irigasi fungsional, harus segera dilakukan oleh pemerintah daerah kabupaten/kota yang memiliki daerah irigasi, dan segera membentuk komisi irigasi.

2. Penyusunan dan penerapan undang-undang yang konsisten tentang pengelolaan sumberdaya air sebagai payung hukum utama bagi sistem pengelolaan daerah irigasi, dan berbagai peraturan pelaksanaannya, terutama peraturan daerah, harus segera direalisasikan.

3. Pengelolaan daerah irigasi di Provinsi Sulawesi Utara dapat disinergiskan dengan program pengelolaan DAS dan program perlindungan lahan pertanian pangan berkelanjutan.

\section{DAFTAR PUSTAKA}

Anonim, 1982. Peraturan Pemerintah Nomor 22 Tahun 1982 Tentang Tata Pengaturan Air.

-, 1982. Peraturan Pemerintah Nomor 23 Tahun 1982 Tentang Irigasi.

-, 2009. Undang-Undang Nomor 41 Tahun 2009 Tentang Perlindungan Lahan Pertanian Pangan Berkelanjutan.

-,2009. Peraturan Pemerintah Nomor 1 Tahun 2011 Tentang Penetapan dan Alih Fungsi Lahan Pertanian Pangan Berkelanjutan.

2012. Peraturan Pemerintah Nomor 37 Tahun 2012 Tentang Pengelolaan Daerah Aliran Sungai.

---------, 2015. Peraturan Menteri Pekerjaan Umum dan Perumahan Rakyat Nomor 12/PRT/M/ 2015 Tanggal 21 April 2015 Tentang Eksploitasi dan Pemeliharaan Jaringan Irigasi. Dalam Himpunan
Perundang-undangan Bidang Sumberdaya Air. Buku 1. Kementerian Pekerjaan Umum dan Perumahan Rakyat, Direktorat Jenderal Sumberdaya Air.

2015. Undang-Undang Nomor 11 Tahun 1974

Tentang Pengairan. Himpunan Perundangundangan Bidang Sumberdaya Air. Buku 1. Kementerian Pekerjaan Umum dan Perumahan Rakyat, Direktorat Jenderal Sumberdaya Air. --, 2015. Peraturan Menteri Pekerjaan Umum dan Perumahan Rakyat Nomor 30/PRT/M/2015 Tanggal 21 April 2015 Tentang Pengembangan dan Pengelolaan Sistem Irigasi. (Diakses di internet pada tanggal 5 Desember 2015).

--, 2015. Peraturan Menteri Pekerjaan Umum dan Perumahan Rakyat Nomor 14/PRT/M/ 2015 Tanggal 21 April 2015 Tentang Kriteria dan Penetapan Status Daerah Irigasi. Dalam Himpunan Peraturan Perundang-undangan Bidang Sumberdaya Air. Buku 2. Kementerian Pekerjaan Umum dan Perumahan Rakyat, Direktorat Jenderal Sumberdaya Air.

----------, 2015. Peraturan Menteri Pekerjaan Umum dan Perumahan Rakyat Nomor 17/PRT/M/2015 Tanggal 21 April 2015 Tentang Komisi Irigasi. Dalam Himpunan Peraturan Perundangundangan. Buku 3. Kementerian Pekerjaan Umum dan Perumahan Rakyat, Direktorat Jenderal Sumberdaya Air.

Amang dan Sawit. 1999. Kebijakan Beras dan Pangan Nasional. Penerbit IPB Press.

BMKG. 2015. Data Jumlah Curah Hujan. Badan Meteorologi Klimatologi dan Geofisika Stasiun Klimatologi Kayuwatu Manado.

BPS Sulut. 2015. Sulut Dalam Angka.

Fauzi A., 2004. Ekonomi Sumberdaya Alam dan Lingkungan Hidup. Penerbit PT Gramedia Pustaka Utama. Jakarta.

Savva A. P. and Frenken K. (2002). Monitoring The Technical and Financial Performance of an Irrigation Scheme. Water Resources Development and Management FAO Sub-Regional Office for East and Southern Africa In collaboration with with Sithole, Simon Madjiwa, and Tove Ijlja. Harare. Diakses pada ftp://ftp.fao.org/ agl/aglv/docs/irrigman14.pdf.

Soekirman and Jus'at, 1994. Food and Nutrition Policies In The Sixth Five Year Development Plan. Indonesian Food Journal No.10 Vol V:6-19. 